\title{
AIR BLAST FREEZING OF FRUIT PULP MODELS IN COMMERCIAL BOXES: INFLUENCE OF PREFERENTIAL CHANNELS IN THE BED ON FREEZING TIMES ESTIMATING ${ }^{1}$
}

\author{
Jaime Vilela de RESENDE ${ }^{2, *}$, Vivaldo SILVEIRA JR. ${ }^{3}$, Lincoln de C. NEVES FILHO ${ }^{3}$
}

\section{SUMMARY}

The freezing times of fruit pulp models packed and conditioned in multi-layered boxes were evaluated under conditions similar to those employed commercially. Estimating the freezing time is a difficult practice due to the presence of significant voids in the boxes, whose influence may be analyzed by means of various methods. In this study, a procedure for estimating freezing time by using the models described in the literature was compared with experimental measurements by collecting time/temperature data. The following results show that the airflow through packages is a significant parameter for freezing time estimation. When the presence of preferential channels was considered, the predicted freezing time in the models could be $10 \%$ lower than the experimental values, depending on the method. The isotherms traced as a function of the location of the samples inside the boxes showed the displacement of the thermal center in relation to the geometric center of the product.

Keywords: freezing times; frozen foods; heat transfer.

\section{RESUMO}

CONGELAMENTO DE MODELOS DE POLPAS DE FRUTAS COM AR FORÇADO. INFLUÊNCIA DE CANAIS PREFERENCIAIS NO LEITO SOBRE AS ESTIMATIVAS DOS TEMPOS DE CONGELAMENTO. Os tempos de congelamento da solução modelo de polpas de frutas embaladas e acondicionadas em diferentes arranjos de camadas no interior das caixas do empilhamento foram avaliados sob várias condições de operação encontradas nas práticas comerciais. Nestes tipos de processos, as caixas contêm uma porosidade significativa e métodos para avaliar como esta afeta o tempo de congelamento, torna o problema de difícil resolução. Procedimentos para as estimativas dos tempos de congelamento, usando modelos encontrados na literatura, foram comparados com medidas experimentais através da aquisição de dados de tempo/temperatura. Os resultados mostraram que o escoamento do ar entre as embalagens é um parâmetro significativo nas estimativas dos tempos de congelamento. Quando é considerada a presença de canais preferenciais, dependendo do método utilizado, estes valores são subestimados em cerca de $10 \%$ quando comparados com os valores experimentais. As isotermas traçadas em função da localização das amostras no interior das caixas comprovam o deslocamento do centro térmico, em relação ao centro geométrico do produto.

Palavras-chave: tempo de congelamento; alimentos congelados; calor-transmissão.

\section{1 - INTRODUCTION}

In Brazil, fruit pulp falls into the important category of frozen foodstuffs that are used in natura and as raw material for ice cream, yogurt and jelly production. As fruit pulp is presented in diverse package types and sizes, a great increase in its production and consumption has been recorded over the last decade.

When fruits are frozen in their pulp form, the effect of the freezing process is verified by the alteration in the consistency of the pulp and through changes in its composition caused by chemical reactions during the subsequent storage. The consistency of the pulp and global appearance is better kept when the fruit pulp is frozen quickly.

In industrial situations, the freezing process of fruit pulp inside boxes with large amounts of product may be very complex. The initial temperature of the product before being submitted to the freezing process may be uniform or not. The homogeneity of the product is not

\footnotetext{
Recebido para publicação em 11/10/2001. Aceito para publicação em $08 / 03 / 2002$.

2. LEST/FEMEC/UFU - Av. João Naves de Àvila, 2160 - Bloco 1 M Campus Santa Mônica - CEP 38400-089. Uberlândia/MG. E-mail: juresende@mecanica.ufu.br.

3. DEA/FEA/ Universidade Estadual de Campinas - Caixa Postal 6121 Cid. Universitária Zeferino Vaz - Distr. Barão Geraldo. CEP 13083-970Campinas/SP - Brazil. E-mails: vivaldo@cers.fea.unicamp.br neveslin@ceres.fea.unicamp.br.

* A quem a correspondência deve ser enviada.
}

guaranteed and there is also the possibility of the existence of void, air bags or bubbles filled with gas inside the product and the packages [2]. The product may have form and regular size, but this does not occur frequently. The external heat transfer can be constant through the entire product surface, but wide variations in heat transfer coefficients, mainly the convective, may occur in different positions [4].

The final quality characteristics of the pulp are reflected by the efficiency of the freezing process, and the time during which the product remains in the process is one of the main factors for its preservation. Industrial processing, in most cases, uses the same operational conditions for different types of products, and the freezing time is pre-established in accordance with the amount of product to be processed. The process is performed in air blast freezers of empirical form and does not posses systematic control of operational parameters which can directly contribute to the reduction of freezing time and can influence the economic aspects of the process and of quality and safety of the product.

Considering the complexity of this industrial process, the objective of this study is to evaluate the effect of the irregularities of the bed (preferential channels) and the amount and product configuration study on the prediction of freezing times of fruits pulp packed in polyethylene bags (100 grams) and conditioned in commercial plastic boxes in air blast freezing process under different operational conditions of the equipment. 


\section{2 - METHODS AND MATERIALS}

\section{1 - Monitoring of the boxes containing the samples}

A system model consisting of $\mathrm{K}$-Carrageenan $0.5 \%$ and sucrose $10 \%$ (mass/volume of water) was used to simulate the fruit pulp. To obtain the description of temperature records during the freezing process, 51 thermocouples (Type T, cooper-constantan) were installed through the entire experimental configuration; with 17 having been installed in each of the three boxes of the pile up in points chosen between the layers of the array of samples such that the transient behavior of the heat transfer during the process could be better translated (Figure 1-A-B).

Each thermocouple was installed in the geometric center of the packages $(100 \mathrm{~g})$. The packages were filled with the product, and after that sealed and placed inside the boxes. In Figure 1-B, the distribution of the samples containing thermocouples inside the boxes is shown for arrays of 3 layers of the product. The position of each thermocouple in the cartesian coordinates system for arrays of 3 layers is presented in Figure 1-C.
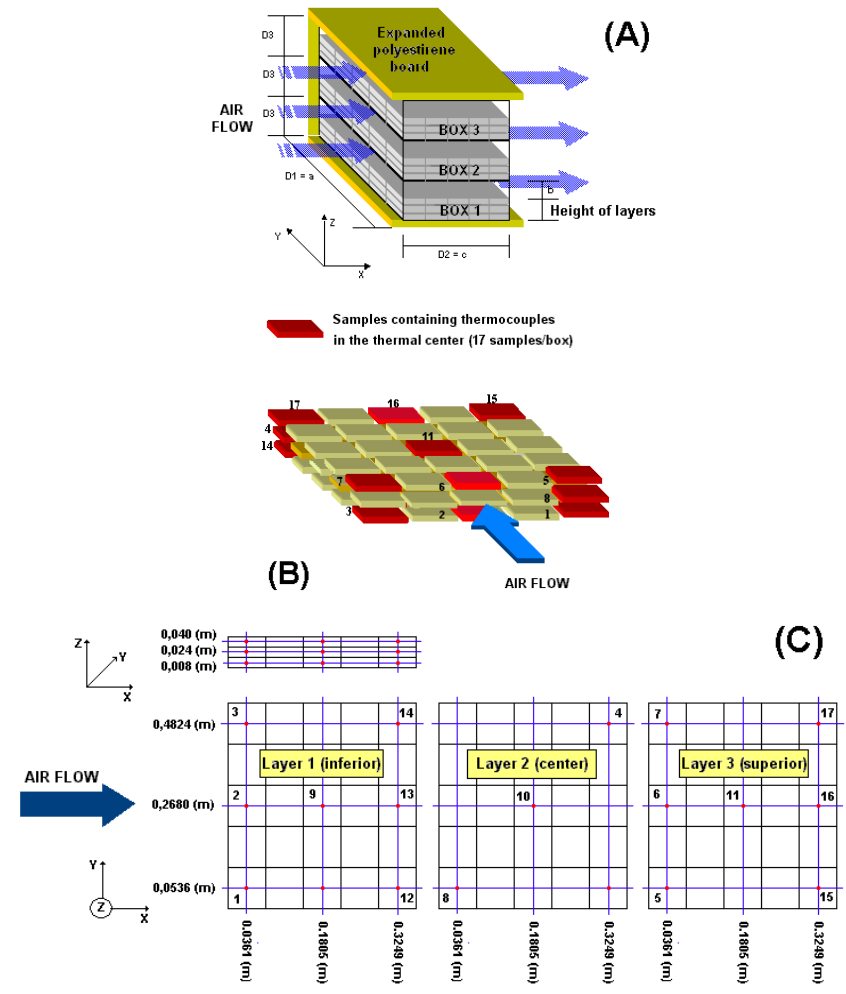

FIGURE 1. (A) Configuration of the boxes in the freezing chamber, array of the 3 layers of product in the boxes, (B) Disposal of the samples containing thermocouples in the geometric center, and (C) thermocouples location in the coordinate system.

\section{2 - Initial stabilization of the temperature of the product}

To provide the initial stabilization of the temperature of the product and the thermal homogeneity of the samples, the entire monitored system, consisting of three boxes containing thermocouples, was placed in a stabilization chamber with an internal room temperature of 25 and $5 \pm 0.5^{\circ} \mathrm{C}$ for a period of 48 hours. These temperatures are commonly used during the industrial process, when the fruit is frozen immediately after it arrived to the facilities or when it is first cooled and frozen later.

\section{3 - Freezing of the product}

After obtaining the stabilization of the equipment at the operating temperature, the three boxes containing the samples ( 3,5 and 7 layers) with thermocouples, were piled up in the freezing chamber. To prevent the formation of preferential channels, expanded polystyrene boards were placed in the lateral sections of the boxes making it so that the air stream of the entire chamber flowed through the openings of the boxes containing the product. The monitoring of the temperature was performed at 1 minute intervals. The temperature of the air cooling was established in 3 levels, $-30,-25$ and $-20^{\circ} \mathrm{C}$ referring to levels 1,2 and 3 respectively.

\section{4 - Thermal properties of the samples}

Data of the thermal properties, specific for food models, for the calculations of heat transfer problems were obtained by means of experimental measurements and compared to structural models, prediction equations and adjusted in terms of polynomial functions, divided in a range of temperatures covering the entire experimental scene. These data are available in RESENDE [10].

\section{5 - Freezing time prediction for samples packed in polyethylene bags and conditioned in boxes.}

For the freezing time prediction of the samples packed in polyethylene bags and conditioned in boxes, the use of the geometric factor was considered for rectangular bricks representing the product inside the boxes (equation 1).

$t_{f}=\frac{t_{f, \text { slab }}}{E}$

\subsection{1 - Freezing time of an infinite slab}

One of the most recommended equations [2, 5] for predicting the freezing time of one-dimensional foodstuffs is presented in the method of PHAM [8] as a basic equation, for which the factor number $(\mathrm{E})$ can be applied. The freezing is calculated by the equation (2). Equation (2) considers the entire freezing process (pre-cooling, phase change and tempering).

$t_{f, s l a b}=\frac{V}{h_{s} A}\left(\frac{\Delta H_{1}}{\Delta T_{1}}+\frac{\Delta H_{2}}{\Delta T_{2}}\right)\left(1+\frac{B i_{s}}{4}\right)$ 
where,

A heat transfer surface area $\left(\mathrm{m}^{2}\right)$;

$\mathrm{Bi}_{\mathrm{s}} \quad$ Biot number $\left(\mathrm{h}_{\mathrm{s}} / \mathrm{RK}\right)$;

$h_{s} \quad$ surface heat transfer coefficient $\left(W / \mathrm{m}^{2} \mathrm{k}\right)$;

$\Delta \mathrm{H}_{\mathrm{i}} \quad$ change in relative enthalpy content $\left(\mathrm{J} / \mathrm{m}^{3}\right), \mathrm{i}=1$ (pre-cooling) and $\mathrm{i}=2$ (freezing and tempering);

$\Delta \mathrm{T}_{\mathrm{i}} \quad$ change in temperature $(\mathrm{K}), \mathrm{i}=1$ (pre-cooling) and $\mathrm{i}=2$ (freezing and tempering);

$\mathrm{V} \quad$ volume $\left(\mathrm{m}^{3}\right)$.

The values for the effective heat transfer coefficients used in the calculations were obtained by the average of the values from the Nusselt versus Reynolds correlations for the different locations (upper and lower layers) in the boxes represented by the equations:

For the superior layer: $\mathrm{Nu}=0,01575 \mathrm{Re}^{0,81439}$

For the inferior layer: $\mathrm{Nu}=0,00754 \mathrm{Re}^{0,85461}$

When $L^{\prime} / D_{H} \leq 60, h=h_{2(\text { eq) }}\left[1+1,4\left(D_{H} / L^{\prime}\right)\right.$, where $h_{2(\text { eq) }}$ is the value from the equation (3) and (4) and $L^{\prime}$ is the length of the duct.

These correlations were developed from the temperatures records of an aluminum transducer with the same dimensions of the samples, in the experimental determination of the airflow rate across the cross section of air blast freezing, and in the concept of the hydraulic diameter, that is established by the amount and number of layers of product inside the boxes [10].

\subsection{2 - Geometric factor calculation (E)}

The geometric factor $(\mathrm{E})$ was calculated using two methods: i) method EHTD ("Equivalent Heat Transfer Dimensions") considered by CLELAND, EARLE [3] given by the equation:

$\mathrm{E}=1+\mathrm{W}_{1}+\mathrm{W}_{2}$

The functions W1 and W2 depend on the Biot number $\left(B i_{s}\right)$ and on the dimensional ratios $\beta_{1}$ and $\beta_{2}$ in accordance with the equations:

$W_{1}=\left(\frac{B i_{s}}{B i_{s}+2}\right) \frac{5}{8 \beta_{1}^{3}}+\left(\frac{2}{B i_{s}+2}\right)\left(\frac{2}{\beta_{1}\left(\beta_{1}+1\right)}\right)$

and $W_{2}=\left(\frac{B i_{s}}{B i_{s}+2}\right) \frac{5}{8 \beta_{2}}+\left(\frac{2}{B i_{s}+2}\right)\left(\frac{2}{\beta_{2}\left(\beta_{2}+1\right)}\right)$

and, ii) the geometric factor $\left(\mathrm{E}_{\mathrm{AN}}\right)$ derived from the analytical solution of heat transfer problems with phase change [7].

$$
\begin{aligned}
& E_{A N}=\left(1+\frac{2}{B i_{s}}\right)\left\{\left(1+\frac{2}{B i_{s}}\right)-4 \sum_{n=1}^{\infty}\left[\frac{\operatorname{sen} Z_{n}}{\left.\left(Z_{n}^{3}\left(1+\frac{\operatorname{sen}^{2} Z_{n}}{B i_{s}}\right) \frac{Z_{n}}{B i_{s}} \operatorname{senh}\left(Z_{n} \beta_{1}\right)+\cosh \left(Z_{n} \beta_{1}\right)\right]\right)}\right]\right. \\
& -8 \beta_{2}^{2} \sum_{n=1}^{\infty} \sum_{m=1}^{\infty}\left[\operatorname { s e n } Z _ { n } \operatorname { s e n } Z _ { m } \left\{\left[\cosh \left(Z_{n m}\right)+\frac{Z_{n m}}{B i_{s}} \frac{1}{\beta_{2}} \operatorname{senh}\left(Z_{n m}\right)\right]\right.\right. \\
& \left.\left.\left.\times Z_{n} Z_{m} Z_{n m}^{2}\left(1+\frac{1}{B i_{s}} \operatorname{sen}^{2} Z_{n}\right)\left(1+\frac{1}{B i_{s} \beta_{1}} \operatorname{sen}^{2} Z_{m}\right)\right\}^{-1}\right]\right\}^{-1}
\end{aligned}
$$

where the values of $Z_{n}$ e $Z_{m}$ are the roots of equations:

$\mathrm{Bi}_{\mathrm{s}}=Z_{\mathrm{n}} \tan Z_{\mathrm{n}}$

and $\mathrm{Bi}_{\mathrm{s}}^{-} \mathrm{b}_{1}=\mathrm{Z}_{\mathrm{m}} \tan \mathrm{Z}_{\mathrm{m}}$

and the values of $Z_{\mathrm{nm}}$ from the equation (11):

$Z_{n m}^{2}=Z_{n}^{2} \beta_{2}^{2}+Z_{m}^{2}\left(\frac{\beta_{2}}{\beta_{1}}\right)^{2}$

The six first roots of equations (9) and (10) are tabled in CARSLAW \& JAEGER [1] as a function of the values of $\mathrm{Bi}_{\mathrm{s}}$ and $\mathrm{Bi}_{\mathrm{s}}{ }^{-} \beta_{1}$.

When trying to find a solution, it was verified that in many configurations tested values for the dimensional ratios $\beta_{1}$ e $\beta_{2}>3$ were found. In accordance with HOSSAIN [6], when this occurs or when the Biot number is under $3\left(\mathrm{Bi}_{\mathrm{s}}<3\right)$, most of the methods become limited and inexact, and, in these cases, the full analytical method must be used for the best prediction of the freezing time.

\section{6 - Geometric configurations}

Two types of configuration of the rectangular bricks that could describe the real environment of the piling up of the boxes containing the samples of the product in air blast freezing were analyzed in accordance with the following proposals (Figure 2): (A) the product inside the boxes was considered as a compact rectangular brick; (B) the product was considered as a group of five identical rectangular bricks evenly spaced inside the boxes with the largest dimensions parallel to the direction of the airflow.

The geometric characteristics of each configuration and the values of the parameters $\left(\beta_{1}, \beta_{2}, V, A, V / A\right)$, used in these equations for the freezing prediction, are shown in Table (1).

\section{7 - Comparison between experimental and calculated results for the freezing times}

The comparison was made through the relation of the difference between predicted and experimental values in accordance with equation: 


$$
e=\frac{\text { Pr edicted }-\exp \text { erimental }}{\text { exp erimental }} \times 100(\%)
$$
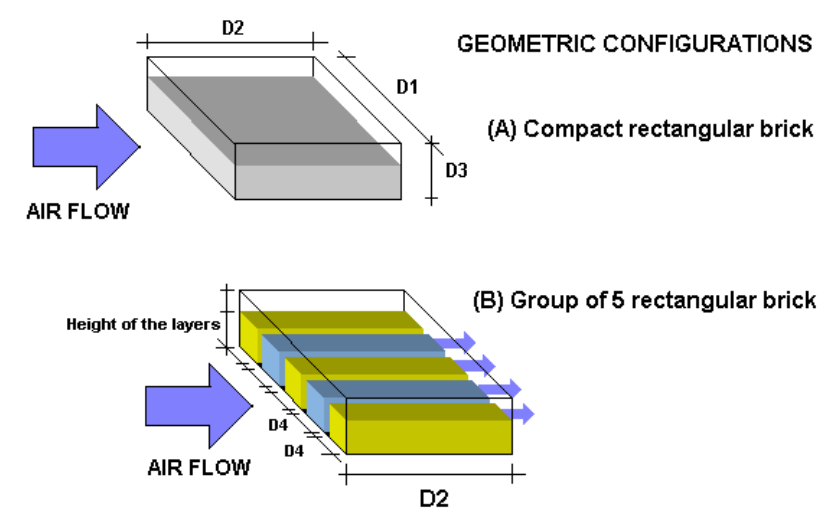

FIGURE 2. Geometric configurations of the product inside the boxes for the freezing times predicting using geometric factors (E). The values of the dimensions shown in the Figure are presented in Table 1.

TABLE 1. Geometric parameters used in the equations for freezing times prediction for the configurations presented in Figure 2.

\begin{tabular}{|c|c|c|c|c|c|c|c|c|c|}
\hline Layers & $\begin{array}{c}\text { Height } \\
(\mathrm{m})\end{array}$ & $\begin{array}{c}\text { Length } \\
(\mathrm{m})\end{array}$ & $\begin{array}{c}\text { Compact rectangular brick } \\
(\mathrm{m})\end{array}$ & $\begin{array}{c}\mathrm{D} \\
(\mathrm{m})\end{array}$ & $\begin{array}{c}\text { Volume } \\
\mathrm{V}\left(\mathrm{m}^{3}\right)\end{array}$ & $\begin{array}{c}\text { Area } \\
\mathrm{A}\left(\mathrm{m}^{2}\right)\end{array}$ & $\begin{array}{c}\mathrm{V} / \mathrm{A} \\
(\mathrm{m})\end{array}$ & $\beta_{1}$ & $\beta_{2}$ \\
\hline 7 & 0,112 & 0,361 & 0,536 & 0,112 & 0,0217 & 0,5879 & 0,0369 & 3,22 & 4,77 \\
\hline 5 & 0,08 & 0,361 & 0,536 & 0,080 & 0,0155 & 0,5305 & 0,0292 & 4,51 & 6,70 \\
\hline 3 & 0,048 & 0,361 & 0,536 & 0,048 & 0,0093 & 0,4731 & 0,0196 & 7,52 & 11,17 \\
\hline 7 & 0,107 & 0,361 & 0,112 & 0,107 & 0,0043 & 0,1823 & 0,0238 & 1,045 & 3,368 \\
\hline 5 & 0,080 & 0,361 & 0,1072 & 0,080 & 0,0031 & 0,1523 & 0,0203 & 1,340 & 4,513 \\
\hline 3 & 0,048 & 0,361 & 0,1072 & 0,048 & 0,0019 & 0,1223 & 0,0152 & 2,233 & 7,521 \\
\hline
\end{tabular}

The standard deviation (SD) was calculated by the equation:

$$
S D=\sqrt{V a r}
$$

where

$$
\operatorname{Var}=\frac{1}{n-1} \sum_{i=1}^{n}\left(e_{i}-\bar{e}\right)^{2}
$$

where $\bar{e}$ is the average error and $\mathrm{n}$ is the size of the sample.

\section{3 - RESULTS AND DISCUSSION}

\section{1 - Curves of freezing}

The graph of Figure 3, shows the descriptions of the temperatures records during the freezing process by the reading of the 17 thermocouples located in box 2 (central), for an experiment with arrays of 3 layers, level 2 of the temperature of the air cooling and initial temperature of the product around $5^{\circ} \mathrm{C}$. It was found that the freezing of the samples located in the front portion of the boxes (coordinates $\mathrm{X}=0,0361 \mathrm{~m}$ ) referring to thermocouples that suffer the direct impact of the airflow originated from the evaporator, presents a faster fall temperature rate when compared to those located in the back portion of the boxes (coordinate $X=0,3249 \mathrm{~m}$ ). It can also be observed that there are notable differences among the temperature records for samples placed between the lower and the upper layers of the boxes and for samples placed in the central points of the different layers.

\section{2 - Thermal center location}

Figure 4 shows the isotherms obtained from the non linear regression built using the temperatures readings from the 17 thermocouples (Figure 1) installed in different positions within box 2 at intervals of 30 minutes during the freezing process. Figure 4 shows this advance on (XY) coordinates system which encloses the width and the length of the box and the movement of the front freezing occurs in a parallel direction to the airflow, and in Figure 5 this advance is seen on the (XZ) plane that represents the perpendicular section to the airflow correspondent to the height and the length of the box. The points of readings are represented by the points shown on the grid and the isotherms are obtained from the averages of these temperatures in function of their locations in the plane. In each assay, 51 temperature records were obtained supplying data for all the piling up.

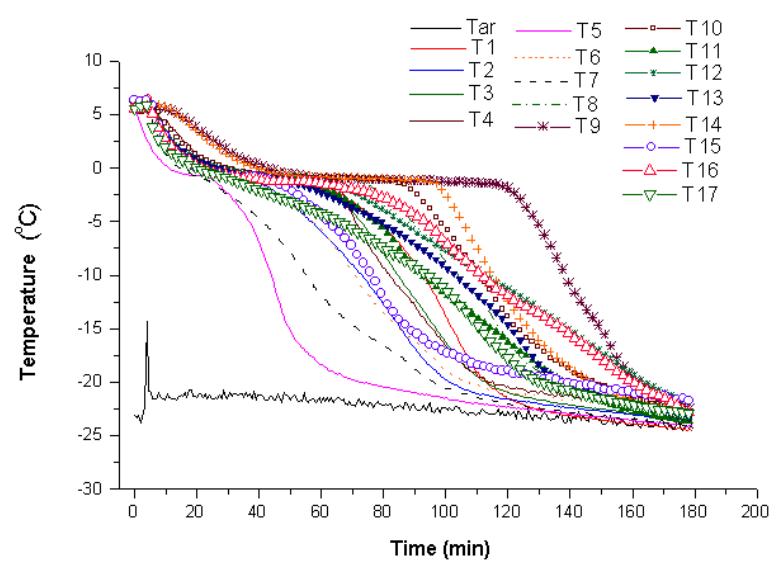

FIGURE 3. Curves of freezing obtained by the responses of the thermocouples located inside the box 2 of the piling up for an experiment with 3 layers and level $2\left(\mathrm{~T}_{\mathrm{ar}}=-22.8^{\circ} \mathrm{C}\right)$ of the air temperature.

Previous work [9, 10] found that there was a significant difference between the effective heat transfer coefficients for the samples placed in different positions (lower and upper) of the layer arrays inside the boxes. These comments suggest that in the different processing conditions it is not possible to obtain a uniform heat transfer in all surfaces of the product and the replacement of the thermal center in the configurations certainly will not occur coinciding with the geometric center of the considered forms. 

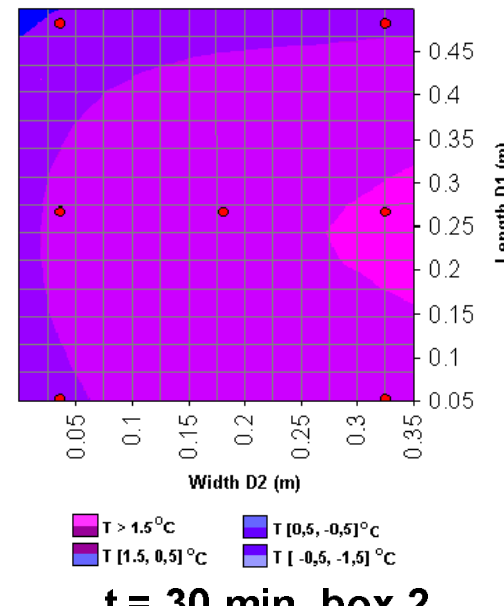

$\mathrm{t}=\mathbf{3 0} \min$, box 2

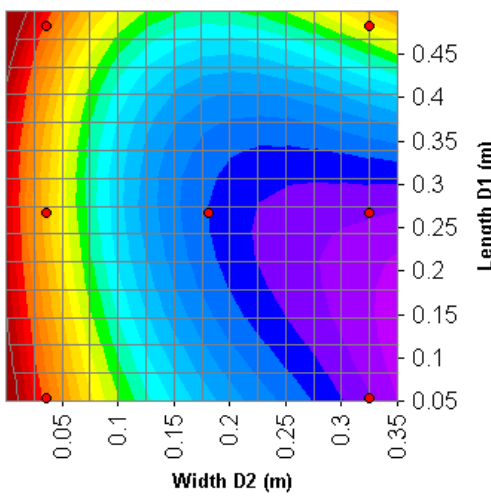

$\mathrm{T}>0{ }^{\circ} \mathrm{C} \quad \square \mathrm{T}[-7,5,12,5]^{\circ} \mathrm{C} \square \mathrm{T}[-17,5,-20]^{\circ} \mathrm{C}$ $\mathrm{T}[0,-2.5]^{\circ} \mathrm{C} T \mathrm{~T}[-12,5,-15]^{\circ} \mathrm{C}$ $\mathrm{T}[-2.5,-5]{ }^{\circ} \mathrm{C} \square \mathrm{T}[-15,-17,5]{ }^{\circ} \mathrm{C} \square \mathrm{T}<-22,5{ }^{\circ} \mathrm{C}$

$t=120 \min$, box 2
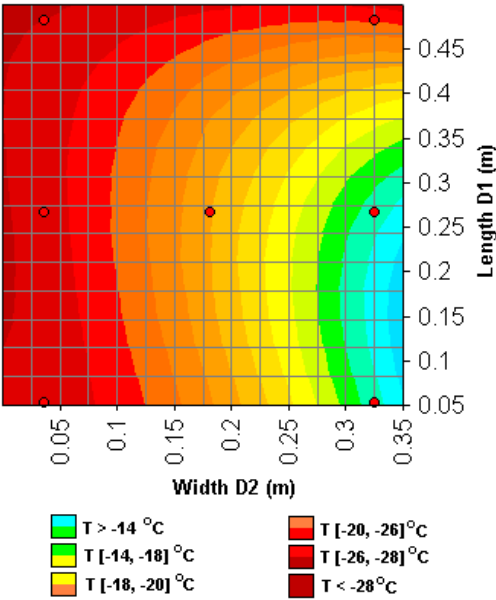

$t=210 \min$, box 2

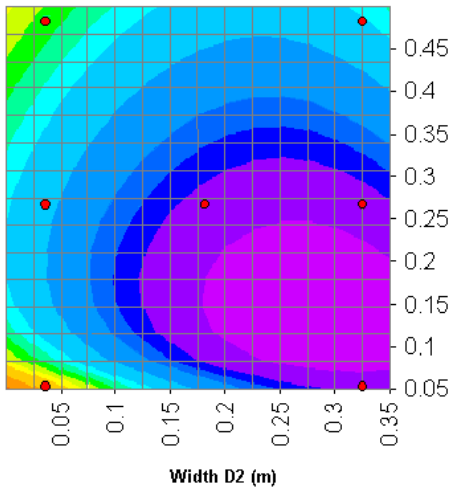

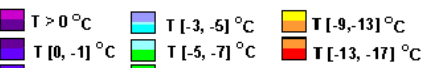

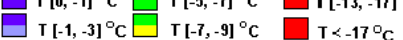

$$
\mathrm{t}=60 \mathrm{~min}, \text { box } 2
$$

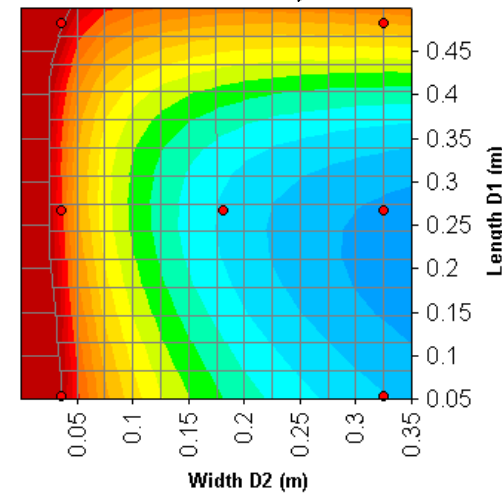

$\mathrm{T}>-5 \quad{ }^{\circ} \mathrm{C} \square \mathrm{T}[-10,-12,5]^{\circ} \mathrm{C} \square \mathrm{T}[-17,5,-22,5]^{\circ} \mathrm{C}$

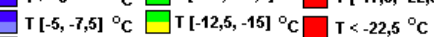
$\mathrm{T}[-7,5,-10]{ }^{\circ} \mathrm{C} \mathrm{T}[-15,-17,5]^{\circ} \mathrm{C}$ $t=150 \mathrm{~min}$, box 2
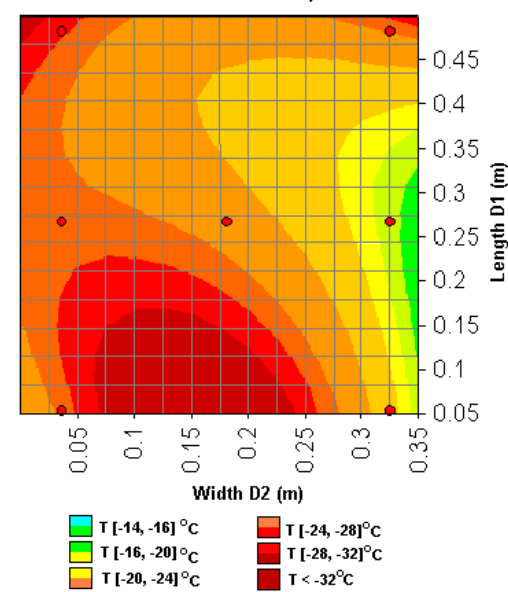

\section{$t=240 \min$, box 2}

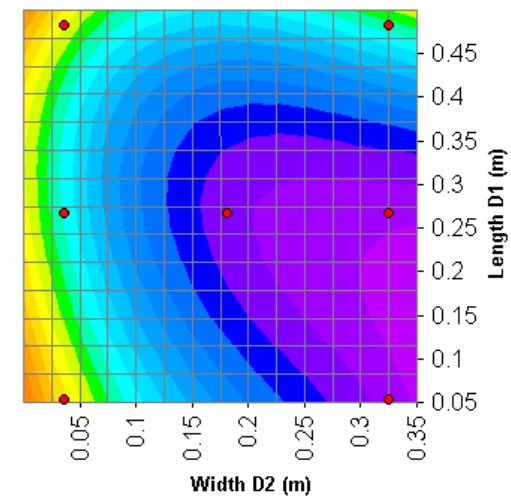

$\square \mathrm{T}>-0,5{ }^{\circ} \mathrm{C} \square \mathrm{T}[-5,-7]{ }^{\circ} \mathrm{C} \square \mathrm{T}[-11,-15]{ }^{\circ} \mathrm{C}$ $\mathrm{T}[-0,5,-2]^{\circ} \mathrm{C} \square \mathrm{T}[-7,-9]{ }^{\circ} \mathrm{C} \quad \mathrm{T}[-15,-20]{ }^{\circ} \mathrm{C}$ $\mathrm{T}[-2,-5]{ }^{\circ} \mathrm{C}-\mathrm{T}[-9,-11]{ }^{\circ} \mathrm{C} \square \mathrm{T}<-20{ }^{\circ} \mathrm{C}$

$t=90 \mathrm{~min}$, box 2

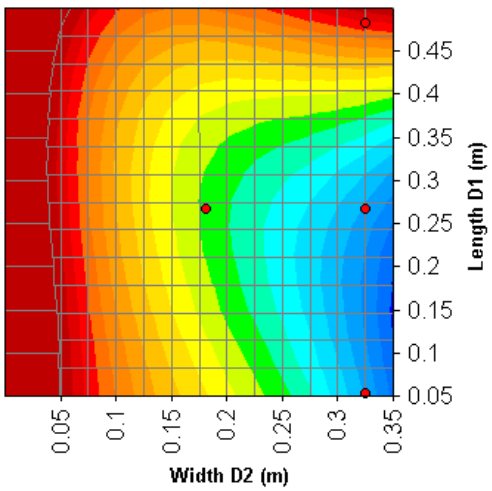

$\square \mathrm{T}>-5 \quad{ }^{\circ} \mathrm{C} \square \mathrm{T}[-10,-12,5]^{\circ} \mathrm{C} \square \mathrm{T}[-17,5,-22,5]^{\circ} \mathrm{C}$ $\mathrm{T}[-5,-7,5]{ }^{\circ} \mathrm{C} \square \mathrm{T}[-12,5,-15]{ }^{\circ} \mathrm{C} \square \mathrm{T}<-22,5{ }^{\circ} \mathrm{C}$ $\mathrm{T}[-7,5,-10]{ }^{\circ} \mathrm{C} \square \mathrm{T}[-15,-17,5]{ }^{\circ} \mathrm{C}$

$t=180 \min$, box 2
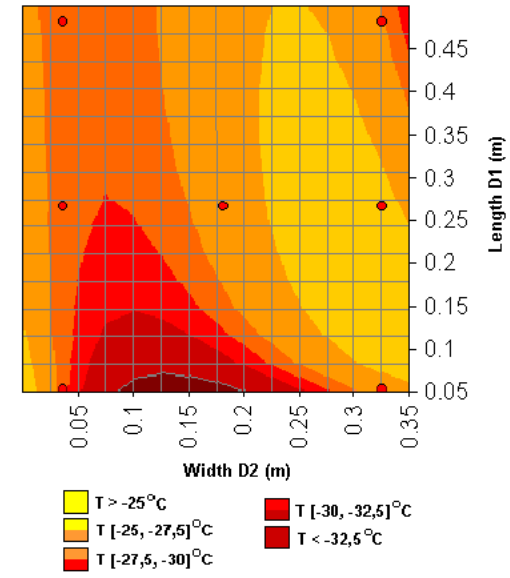

\section{$t=270 \min$, box 2}

FIGURE 4. Isotherms adjusted'by non linear regression in location function in the plan (XY) of the coordinate systems for experiments

realized with arrays of 7 layers and level 1 of air temperature. For reference of the coordinates, to see Figure 1-C.

Figures 4 and 5 prove the replacement of the thermal center compared to the geometric center of the product during the freezing and show that the samples placed in the second half of the (XY) plane of the configurations are the last ones to be frozen and the front freezing is sped up in the direction of the airflow.
It is observed that the replacement of the front freezing occurs in all surfaces, and the velocity of advance in direction to the thermal center is more noticeable from the front surface and on the upper layers of the boxes containing the samples. Therefore in these cases, the shape of the product is such that the heat transfer occurs 


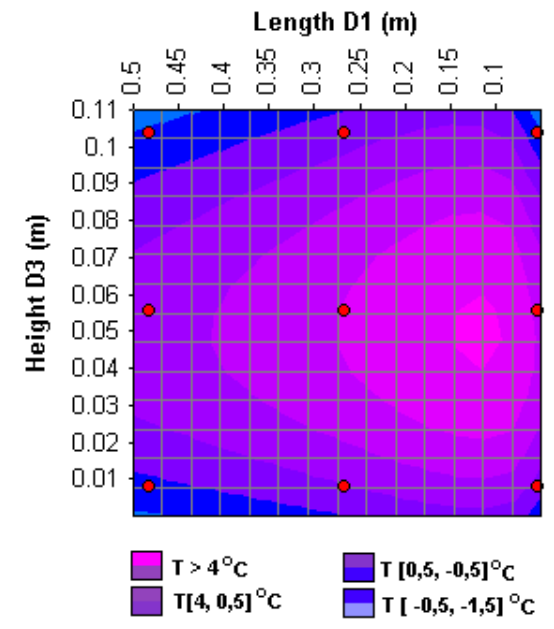

\section{$\mathrm{t}=30 \mathrm{~min}$, box 2}

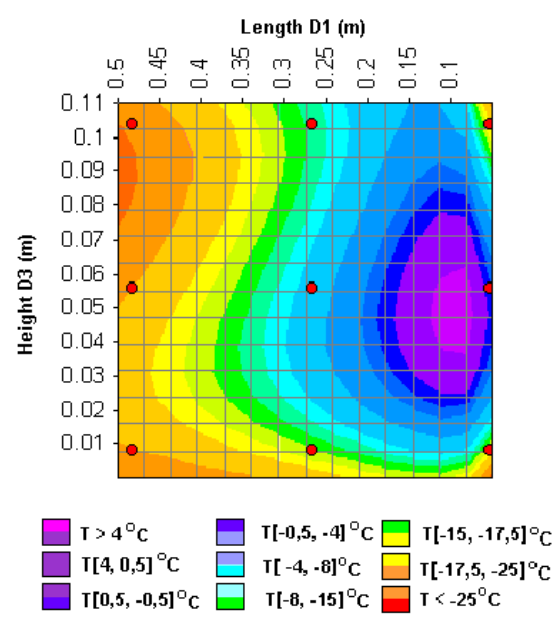

$\mathrm{t}=180 \mathrm{~min}$, box 2

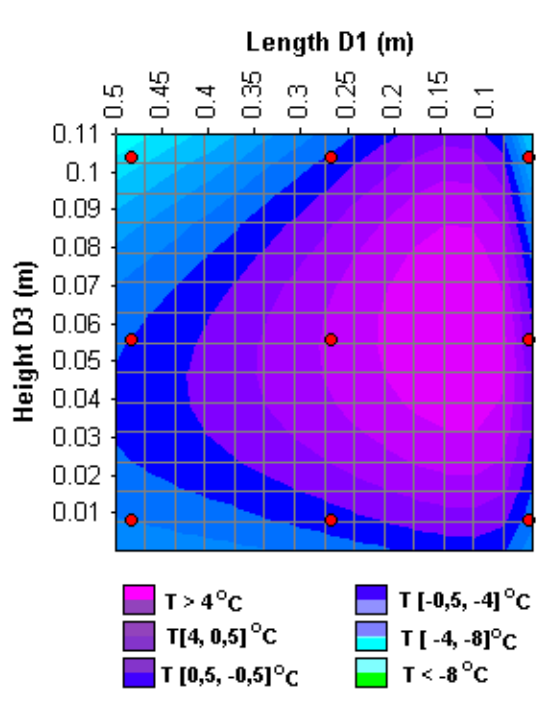

\section{$\mathrm{t}=60 \mathrm{~min}$, box 2}

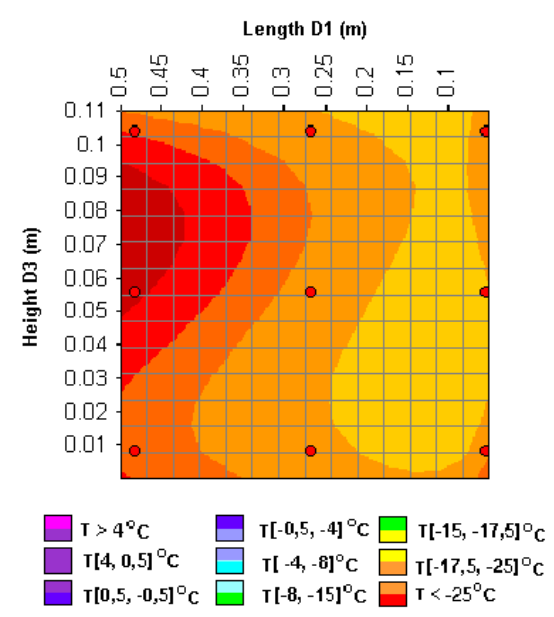

$\mathrm{t}=240 \mathrm{~min}$, box 2
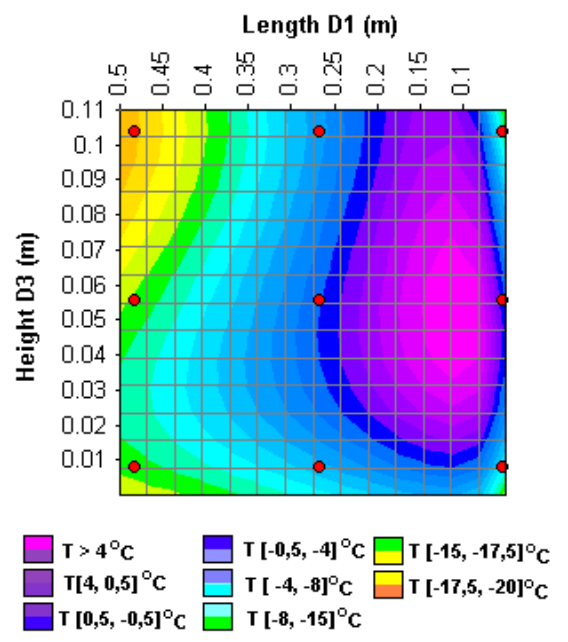

\section{$\mathrm{t}=120 \mathrm{~min}, \operatorname{box} 2$}

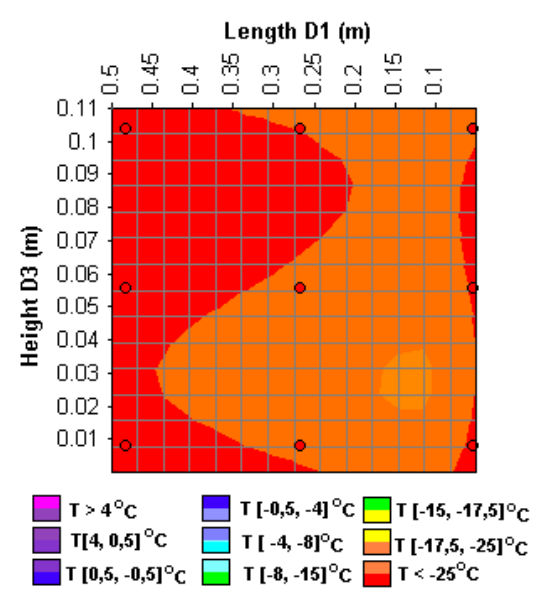

$\mathrm{t}=270 \mathrm{~min}$, box 2

FIGURE 5. Isotherms adjusted by non linear regression in location function in the plan (YZ) of the coordinate systems for experiments realized with arrays of 7 layers and level 1 of air temperature. For reference of the coordinates, to see Figure 1-C.

in more than one direction and the calculations of the freezing time, must be dealt using models for multidimensional forms, as considered previously.

The thermal center is defined as the last point of the foodstuffs to suffer changes in temperature from the freezing process. In all the experiments the final temperature of thermal center $\left(\mathrm{T}_{\mathrm{c}}\right)$ was of $-18^{\circ} \mathrm{C}$ and the experimental freezing time was taken when all the thermocouples placed in all the configuration had shown lower temperatures immediately after this.

\section{3 - Evaluation of the freezing times for samples conditioned inside the boxes}

Table 2 shows the experimental freezing times for all the configuration proposals when the initial temperatures $\left(\mathrm{T}_{\mathrm{i}}\right)$ of the product was around $25^{\circ} \mathrm{C}$ and $5^{\circ} \mathrm{C}$ after stabilization. In Table 3 the results of the methods for the calculation of the geometric factor (E) are presented using the two methods and for the two configuration proposals.

The different methods for the calculation of the geometric factor have been tested by its authors mainly using data obtained from simulation tests. In accordance with SALVADORI, DE MICHAELIS, MASCHERONI [11], the correct way to verify the effectiveness of a predictive method is to verify the predictions that correspond to an available experimental data set. In this study, (Table 2) 36 experimental assays were performed, with varied geometric configurations of the product, initial temperatures and operational conditions of the equipment. Tables 4 and 5 show the average errors and standard deviation of the freezing times using the methods tested for these data. The results are divided by the geometric factor method of calculation, by the level of air temperature and by the configuration type considered. Figures 6 and 7 allow a better visualization 
for comparison of the results, showing the data of Tables 4 and 5 through bar diagrams.

It is observed that for the configuration that considers the product as a compact rectangular brick, the freezing times predicted by the models are overestimated, in some cases, with upper average errors of $100 \%$ when compared with the experimental freezing times, independently of the method of calculation and of the geometric factor. This configuration does not consider the empty spaces between the samples, and, the superficial area of heat transfer applied to the calculations is reduced not describing the real situation of the passage of air cooled through the product inside the freezing chamber. For the other configuration the existence of preferential channels between the samples is considered and the average errors produced by the models, are sufficiently reduced.

TABLE 2. Experimental freezing times.

\begin{tabular}{|c|c|c|c|c|c|c|c|c|c|}
\hline \multicolumn{10}{|c|}{ Experimental freezing times (hours) } \\
\hline Layers & Box & $\mathrm{T}_{\operatorname{ar}}\left({ }^{\circ} \mathrm{C}\right)$ & $\mathrm{T}_{\mathrm{i}}\left({ }^{\circ} \mathrm{C}\right)$ & $t_{\text {exp. }}(h)$ & $\operatorname{Tar}\left({ }^{\circ} \mathrm{C}\right)$ & $\mathrm{T}_{\mathrm{i}}\left({ }^{\circ} \mathrm{C}\right)$ & \multicolumn{3}{|c|}{$t_{\text {exp. (3 replicate) }}$} \\
\hline 7 & 3 & $-28,4^{*}$ & 6,5 & 3,31 & $-27,2^{*}$ & 25,2 & 4,32 & 4,25 & 4,42 \\
\hline 7 & 2 & $-28,4$ & 7,7 & 3,64 & $-27,3^{*}$ & 25,2 & 4,53 & 4,85 & 4,17 \\
\hline 7 & 1 & $-28,4$ & 6,7 & 3,84 & $-26,5^{*}$ & 24,7 & 4,87 & 4,55 & 4,19 \\
\hline 5 & 3 & $-28,3$ & 5,6 & 2,94 & $-27,1^{*}$ & 24,1 & 3,05 & 3,24 & 3,39 \\
\hline 5 & 2 & $-28,3^{*}$ & 5,9 & 3,08 & $-28,6^{\circ}$ & 22,7 & 3,69 & 3,38 & 4,18 \\
\hline 5 & 1 & $-28,3^{*}$ & 5,5 & 3,35 & $-29,5^{*}$ & 23 & 3,5 & 3,95 & 4,98 \\
\hline 3 & 3 & $-28,3^{*}$ & 5,2 & 2,52 & $-30,5^{*}$ & 24,3 & 1,98 & 2,94 & 2,97 \\
\hline 3 & 2 & $-28,3^{*}$ & 5,5 & 2,66 & $-31,2$ & 23,7 & 2,95 & 2,56 & 2,55 \\
\hline 3 & 1 & $-28,3^{*}$ & 4,5 & 2,71 & $-31,2$ & 24 & 2,16 & 3,06 & 3,78 \\
\hline 7 & 3 & $-21,1$ & 8,3 & 4,5 & $-23,2$ & 25 & 4,75 & 5,58 & 5,13 \\
\hline 7 & 2 & $-21,1^{\circ}$ & 8,8 & 5,47 & $-25,1^{*}$ & 27,1 & 4,91 & 4,92 & 5,93 \\
\hline 7 & 1 & $-21,1^{*}$ & 6,0 & 5,39 & $-24,7^{*}$ & 26,4 & 5,25 & 5,63 & 5,06 \\
\hline 5 & 3 & $-23,7$ & 6,4 & 3,6 & $-22,7^{*}$ & 22,5 & 4,53 & 4,99 & 4,34 \\
\hline 5 & 2 & $-23,7$ & 6,5 & 3,48 & $-22,4$ & 23,2 & 4,92 & 4,55 & 4,92 \\
\hline 5 & 1 & $-23,7$ & 5,9 & 4,1 & $-22,8$ & 23,4 & 4,41 & 4,94 & 4,6 \\
\hline 3 & 3 & $-23,2$ & 5,4 & 3,27 & $-20,9^{*}$ & 24,5 & 3,49 & 3,23 & 3,36 \\
\hline 3 & 2 & $-23,2$ & 6,1 & 3,83 & $-21,4$ & 25,3 & 3,11 & 3,85 & 3,64 \\
\hline 3 & 1 & $-23,2^{*}$ & 5,2 & 3,57 & $-22,7^{*}$ & 23,9 & 4,41 & 3,36 & 3,89 \\
\hline 7 & 3 & $-18,6^{*}$ & 6,2 & 7 & $-17,3^{*}$ & 26,4 & 11,17 & 11,28 & 11 \\
\hline 7 & 2 & $-18,6^{*}$ & 6,0 & 7,74 & $-16,6^{\circ}$ & 26,1 & 12,9 & 12,75 & 11,15 \\
\hline 7 & 1 & $-18,6^{*}$ & 6,2 & 7,74 & $-17,5^{*}$ & 25,5 & 12,27 & 12,5 & 12,91 \\
\hline 5 & 3 & $-17,5^{\circ}$ & 5,3 & 4,85 & $-17,7^{\circ}$ & 25,4 & 7,15 & 7,39 & 7,06 \\
\hline 5 & 2 & $-17,5^{\circ}$ & 5,4 & 5,03 & $-17,5^{*}$ & 25,3 & 7,93 & 7,95 & 7,06 \\
\hline 5 & 1 & $-17,5^{\circ}$ & 5,4 & 5,52 & $-17^{\circ}$ & 25,4 & 7,34 & 8 & 7,86 \\
\hline 3 & 3 & $-18,7^{*}$ & 5,4 & 3,61 & $-17^{*}$ & 23,2 & 5,46 & 5,7 & 4,86 \\
\hline 3 & 2 & $-18,7^{*}$ & 5,3 & 3,28 & $-17^{\star}$ & 24 & 5,52 & 5,45 & 5,24 \\
\hline 3 & 1 & $-18,7^{*}$ & 4,5 & 4,41 & $-18,5^{\circ}$ & 24,3 & 5 & 5,46 & 5,45 \\
\hline
\end{tabular}

* Average temperature of the air during the freezing process

The best results are observed when the configuration applied to the model is an array consisting of 5 rectangular bricks of the product evenly spaced with its largest dimensions parallel to the airflow direction. In this configuration, for arrays of 7 layers of samples, the predicted freezing times are underestimated, however the average errors when compared to the experimental results are reduced. For procedures with arrays of 5 and 3 layers of samples, this type of configuration applied to the models yielded good results with average errors of prediction $12 \%$ lower when compared to the experimental values. This model considers the passage of air through preferential channels parallel to the air flow direction formed between a group of samples and an increase in the surface of heat transfer because it includes in the lateral area of the individual samples inside the bed into the calculations.

The effectiveness of the prediction method can be noticed when the procedure applied to the prediction models was the one constituted by arrays of various bricks inside the boxes (configuration B) and the geometric factor $\left(\mathrm{E}_{\mathrm{AN}}\right)$ was calculated using the equation (8) of HOSSAIN, CLELAND, CLELAND [7] developed by the analytical solution of heat transfer problems in the transient state.

TABLE 3. Geometric factors for rectangular bricks calculated by the model of CLELAND, EARLE [3] (E) and by formulas derived from analytical solutions of HOSSAIN [6] $\left(\mathrm{E}_{\mathrm{AN}}\right)$ for different considered geometric configurations.

\begin{tabular}{|c|c|c|c|}
\hline \multicolumn{4}{|c|}{ Geometric factors used in the prediction equations } \\
\hline \multirow{2}{*}{\multicolumn{2}{|c|}{$\begin{array}{l}\text { Geometric } \\
\text { factor }\end{array}$}} & \multicolumn{2}{|c|}{ Configurations } \\
\hline & & Compact brick & Array of 5 bricks \\
\hline \multirow{9}{*}{$\mathrm{E}$} & 7 & 1.172737 & 1.957895 \\
\hline & 7 & 1.173501 & 1.959802 \\
\hline & 7 & 1.17355 & 1.959923 \\
\hline & 5 & 1.098468 & 1.630875 \\
\hline & 5 & 1.098903 & 1.632709 \\
\hline & 5 & 1.096477 & 1.625047 \\
\hline & 3 & 1.040312 & 1.275139 \\
\hline & 3 & 1.040651 & 1.277134 \\
\hline & 3 & 1.040704 & 1.277444 \\
\hline \multirow{9}{*}{$E_{\text {AN }}$} & 7 & 1.098815 & 1.830451 \\
\hline & 7 & 1.100766 & 1.831396 \\
\hline & 7 & 1.100887 & 1.831807 \\
\hline & 5 & 1.051247 & 1.60737 \\
\hline & 5 & 1.053136 & 1.610799 \\
\hline & 5 & 1.05414 & 1.612617 \\
\hline & 3 & 1.015317 & 1.311493 \\
\hline & 3 & 1.016935 & 1.316507 \\
\hline & 3 & 1.017318 & 1.321461 \\
\hline
\end{tabular}

The method presented good values for the freezing time prediction when compared to the experimental results in all levels of air temperature, with results more compatible for experiments with arrays of 5 and 3 layers of samples inside of the boxes. For the freezing time prediction for boxes containing arrays of 7 layers, a great difference between the predicted and experimental values was observed, but when compared to the other applied conditions, it presented the lesser average prediction errors. The presence of these channels inside the boxes between the samples increase the heat transfer rate by increasing the air velocity, and, is probably, also influenced by edge effect and sudden changes of the air direction in these spaces. The first type of tested configuration (compact rectangular bricks) does not consider the existence of these channels. 


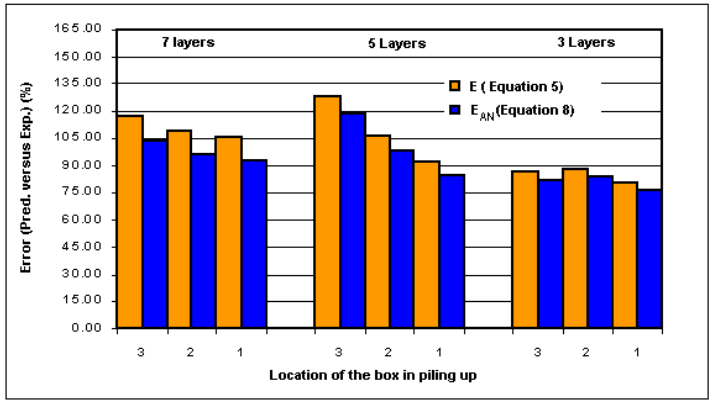

A) Compact rectangular brick, level 1 of air temperature

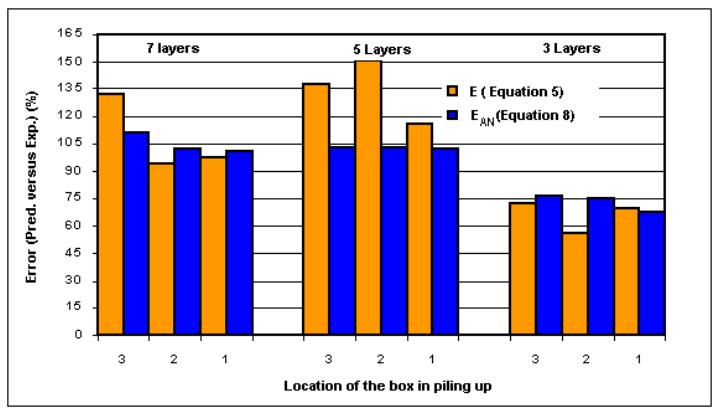

B) Compact rectangular brick, level 2 of air temperature

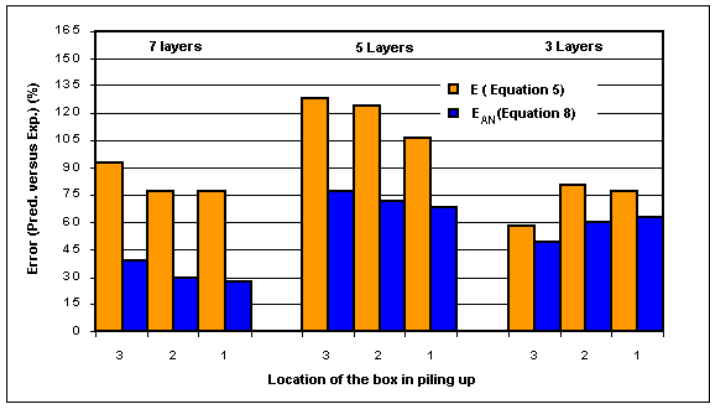

C) Compact rectangular brick, level 3 of air temperature

FIGURE 6. Average errors obtained for the prediction of the freezing times from different methods of geometric factor calculation and considering the product as a compact rectangular brick.

\section{4 - CONCLUSIONS}

A method of prediction developed for regular forms must be used with certain care in situations where apparently the conformation of the product is similar. It is necessary to consider the presence of preferential channels, voids and irregularities that can exist in the product or in the shape during processing. In this study, it was found that differences in the behavior of the cooling rate exist between the boxes placed in different positions of the pile, and that the heat transfer occurs in all the directions and is not uniform in all the surfaces. When the details of the flow are not taken into account, average errors in the estimation of freezing times has been above

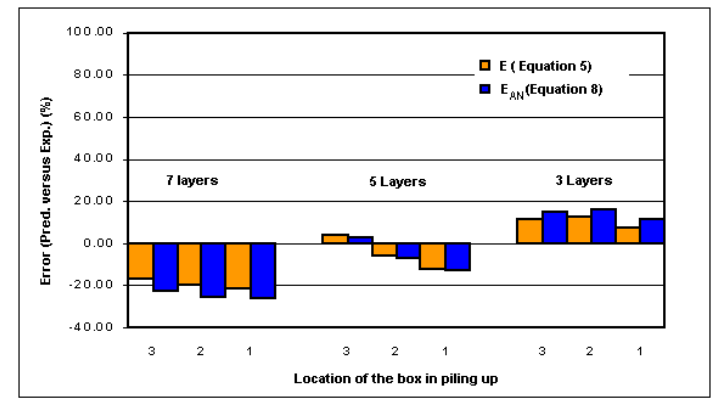

A) Array of rectangular bricks, level 1 of air temperature

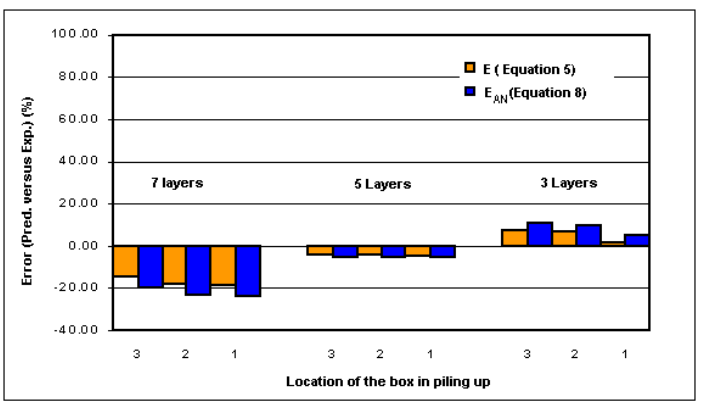

B) Array of rectangular bricks, level 2 of air temperature

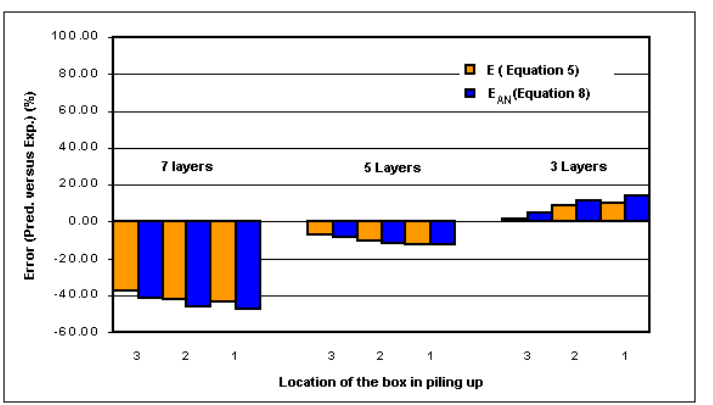

C) Array of rectangular bricks, level 3 of air temperature

FIGURE 7. Average errors obtained for the prediction of the freezing times from different methods of geometric factor calculation and considering the product as a group of 5 rectangular bricks with the largest dimensions parallel to the air flow direction.

$100 \%$ in some cases. On the other hand, the configuration that considers the existence of preferential channels in the bed yielded good results in all the tested levels of temperature, resulting in average errors of the predicted values below $10 \%$. The heat transfer coefficients greatly affect the accuracy of the prediction methods, and in a previous work [10], specific correlations from measures in this experimental procedure were developed. Therefore, a prediction method needs: to be tested and compared with experimental data, to have quality in the measurements, and, an analysis must be made to represent the configuration of the experimental environment to get compatible estimates with the real process applicable in the calculations of engineering. 
TABLE 4. Statistic analysis of the results obtained for the freezing times from different methods of the geometric factor calculation and considering the product as a compact rectangular brick.

\begin{tabular}{|c|c|c|c|c|c|}
\hline \multirow{3}{*}{\multicolumn{2}{|c|}{$\begin{array}{c}\text { TEMPERATURE } \\
\text { Layers -box }\end{array}$}} & \multicolumn{4}{|c|}{ GEOMETRIC FACTOR } \\
\hline & & \multicolumn{2}{|c|}{$E$} & \multicolumn{2}{|c|}{$E_{A N}$} \\
\hline & & $\bar{e} \quad \%$ & SD \% & $\begin{array}{ll}\bar{e} & \%\end{array}$ & SD \% \\
\hline \multirow{9}{*}{ Level 1} & $7-3$ & $+103,66$ & 21,75 & $+117,36$ & 23,21 \\
\hline & $7-2$ & $+95,93$ & 18,79 & $+108,87$ & 20,04 \\
\hline & $7-1$ & $+92,66$ & 14,97 & $+105,38$ & 15,96 \\
\hline & $5-3$ & $+118,30$ & 9,80 & $+128,10$ & 10,24 \\
\hline & $5-2$ & $+97,95$ & 20,71 & $+106,55$ & 21,61 \\
\hline & $5-1$ & $+84,81$ & 28,00 & $+92,23$ & 29,13 \\
\hline & $3-3$ & $+81,88$ & 37,19 & $+86,36$ & 38,10 \\
\hline & $3-2$ & $+83,58$ & 13,51 & $+87,87$ & 13,83 \\
\hline & $3-1$ & $+76,12$ & 41,74 & $+80,16$ & 42,70 \\
\hline \multirow{9}{*}{ Level 2} & $7-3$ & $+110,91$ & 14,45 & $+125,10$ & 15,42 \\
\hline & $7-2$ & $+102,01$ & 22,24 & $+115,36$ & 23,71 \\
\hline & $7-1$ & $+100,22$ & 13,57 & $+113,44$ & 14,46 \\
\hline & $5-3$ & $+102,87$ & 20,10 & $+111,98$ & 21,00 \\
\hline & $5-2$ & $+103,37$ & 25,90 & $+112,20$ & 27,02 \\
\hline & $5-1$ & $+102,27$ & 10,01 & $+110,39$ & 10,42 \\
\hline & $3-3$ & $+76,21$ & 7,78 & $+80,55$ & 7,97 \\
\hline & $3-2$ & $+74,91$ & 22,37 & $+78,99$ & 22,89 \\
\hline & $3-1$ & $+67,44$ & 18,77 & $+71,29$ & 19,20 \\
\hline \multirow{9}{*}{ Level 3} & $7-3$ & $+39,48$ & 27,38 & $+48,87$ & 29,22 \\
\hline & $7-2$ & $+28,99$ & 25,83 & $+37,51$ & 27,53 \\
\hline & $7-1$ & $+26,74$ & 26,31 & $+35,10$ & 28,05 \\
\hline & $5-3$ & $+76,81$ & 27,64 & $+84,75$ & 28,89 \\
\hline & $5-2$ & $+71,56$ & 30,05 & $+79,02$ & 31,36 \\
\hline & $5-1$ & $+68,08$ & 21,38 & $+74,83$ & 22,24 \\
\hline & $3-3$ & $+49,46$ & 10,52 & $+53,14$ & 10,78 \\
\hline & $3-2$ & $+60,31$ & 11,15 & $+64,05$ & 11,41 \\
\hline & $3-1$ & $+62,96$ & 9,31 & $+66,71$ & 9,52 \\
\hline
\end{tabular}

\section{5 - REFERENCES}

[1] CARSLAW, H. S.; JAEGER, J. C. Conduction of heat in solids. 2th Edition, Oxford University Press, 1959.

[2] CLELAND, A. C. Food refrigeration process. Analysis, design and simulation. Elsevier Applied Science: London e New York. 284p., 1990.

[3] CLELAND, A. C.; EARLE; R. L. Freezing time prediction for foods - a simplified procedure. International Journal of Refrigeration, v.5, n.3, p.134-140, 1982

[4] CLELAND, A.C.; ÔZILGEN, S. Thermal design calculations for food freezing equipment- past, present and future. International Journal of Food Refrigeration, v. 21, n. 5, p. 359-371, 1998.

[5] DELGADO, A. E.; DA-WEN SUN Heat and mass transfer models for predicting freezing process - a review. Journal of Food Engineering, v.47, p.157-174, 2001

[6] HOSSAIN, M. M. A simple method of freezing time calculation for foodstuffs of various shapes. Food Austrália, v.47, n.3, p. 109-112, 1995.

[7] HOSSAIN, M. M., CLELAND, D. J.; CLELAND, A. C. Prediction of freezing and thawing times for foods of regular multidimensional shape by using an analytically derived
TABLE 5. Statistic analysis of the results of the freezing times for different methods of calculation of the geometric factor and considering the product as a group of 5 rectangular bricks with the largest dimensions parallel to the airflow direction.

\begin{tabular}{|c|c|c|c|c|c|}
\hline \multirow{3}{*}{\multicolumn{2}{|c|}{$\begin{array}{c}\text { TEMPERATURE } \\
\text { Layers-box }\end{array}$}} & \multicolumn{4}{|c|}{ GEOMETRIC FACTOR } \\
\hline & & \multicolumn{2}{|c|}{$\mathrm{E}$} & \multicolumn{2}{|c|}{$E_{A N}$} \\
\hline & & $\begin{array}{ll}\bar{e} & \%\end{array}$ & SD \% & $\%$ & SD \% \\
\hline \multirow{9}{*}{ Level 1} & $7-3$ & $-22,14$ & 8,25 & $-16,72$ & 8,83 \\
\hline & $7-2$ & $-25,11$ & 7,14 & $-19,86$ & 7,64 \\
\hline & $7-1$ & $-26,36$ & 5,69 & $-21,20$ & 6,09 \\
\hline & $5-3$ & $+2,66$ & 4,59 & $+4,16$ & 4,66 \\
\hline & $5-2$ & $-6,98$ & 9,69 & $-5,72$ & 9,83 \\
\hline & $5-1$ & $-12,94$ & 13,17 & $-12,27$ & 13,27 \\
\hline & 3-3 & $+15,03$ & 23,54 & $+11,84$ & 22,89 \\
\hline & $3-2$ & $+15,96$ & 8,57 & $+12,49$ & 8,31 \\
\hline & $3-1$ & $+11,22$ & 26,37 & $+7,51$ & 25,49 \\
\hline \multirow{9}{*}{ Level 2} & $7-3$ & $-19,84$ & 5,28 & $-14,26$ & 5,65 \\
\hline & $7-2$ & $-23,17$ & 9,09 & $-17,78$ & 9,73 \\
\hline & $7-1$ & $-23,86$ & 5,93 & $-18,54$ & 6,34 \\
\hline & $5-3$ & $-5,22$ & 8,32 & $-3,83$ & 8,44 \\
\hline & $5-2$ & $-5,09$ & 10,75 & $-3,80$ & 10,89 \\
\hline & $5-1$ & $-5,27$ & 4,41 & $-4,54$ & 4,45 \\
\hline & 3-3 & $+10,84$ & 5,98 & $+7,76$ & 5,82 \\
\hline & $3-2$ & $+9,94$ & 15,02 & $+6,65$ & 14,57 \\
\hline & $3-1$ & $+5,15$ & 12,04 & $+1,64$ & 11,64 \\
\hline \multirow{9}{*}{ Level 3} & $7-3$ & $-41,50$ & 6,97 & $-37,43$ & 7,46 \\
\hline & $7-2$ & $-45,90$ & 7,05 & $-42,10$ & 7,54 \\
\hline & $7-1$ & $-46,88$ & 6,93 & $-43,17$ & 7,41 \\
\hline & $5-3$ & $-8,60$ & 7,52 & $-7,26$ & 7,63 \\
\hline & $5-2$ & $-11,43$ & 9,41 & $-10,23$ & 9,54 \\
\hline & $5-1$ & $-12,82$ & 5,33 & $-12,15$ & 5,37 \\
\hline & $3-3$ & $+4,60$ & 8,86 & $+1,70$ & 8,62 \\
\hline & $3-2$ & $+11,80$ & 2,53 & $+8,45$ & 2,46 \\
\hline & $3-1$ & $+13,77$ & 5,78 & $+9,98$ & 5,59 \\
\hline
\end{tabular}

geometric factor. International Journal of Refrigeration, v.15, n.4, p.227-234, 1992.

[8] PHAM, Q. T. Simplified equation for predicting the freezing time of foodstuffs. Journal of Food Technology, v.21, p.209-219, 1986.

[9] PHAM, Q.T.; WILLIX, J. Heat transfer coefficients in the air blast freezing of rows of cartons. Proceedings $17 \mathbf{t}^{\mathrm{h}}$ Int. Congress of Refrigeration., pp.350-357, 1987.

[10] RESENDE, J. V. Heat transfer analyses for the freezing of fruit pulps in commercial boxes. Campinas, 2001. (D.Sc. thesis in Food Engineering), Faculty of Food Engineering, State University of Campinas (UNICAMP).

[11] SALVADORI, V. O., DE MICHAELIS; MASCHERONI, R. H. Prediction of freezing times for regular multi-dimensional foods using simple formulae. Lebensmittel Wissenchaft und Technology. v.30, p.30-35, 1997.

\section{6 - ACKNOWLEDGEMENTS}

Acknowledgements are made to CNPq (Conselho Nacional de Desenvolvimento Científico e Tecnológico) for financially supporting this study. 